\title{
Does Tyrosine Protect S. Coelicolor Laccase from Oxidative Degradation?
}

\author{
Patrycja Kielb, Harry B. Gray, Jay R. Winkler
}

Submitted date: $18 / 07 / 2020$ - Posted date: 20/07/2020

Licence: CC BY-NC-ND 4.0

Citation information: Kielb, Patrycja; Gray, Harry B.; Winkler, Jay R. (2020): Does Tyrosine Protect S. Coelicolor Laccase from Oxidative Degradation?. ChemRxiv. Preprint. https://doi.org/10.26434/chemrxiv.12671612.v1

We have investigated the roles of tyrosine (Tyr) and tryptophan (Trp) residues in the four-electron reduction of oxygen catalyzed by Streptomyces coelicolor laccase (SLAC). During normal enzymatic turnover in laccases, reducing equivalents are delivered to a type $1 \mathrm{Cu}$ center $\left(\mathrm{Cu}_{\mathrm{T} 1}\right)$ and then are transferred over $13 \AA$ to $\mathrm{a}$ trinuclear $\mathrm{Cu}$ site (TNC: $\left.\left(\mathrm{Cu}_{\mathrm{T} 3}\right)_{2} \mathrm{Cu}_{\mathrm{T} 2}\right)$ where $\mathrm{O}_{2}$ reduction occurs. The TNC in SLAC is surrounded by a large cluster of Tyr and Trp residues that can provide reducing equivalents when the normal flow of electrons is disrupted. Canters and coworkers have shown that when $\mathrm{O}_{2}$ reacts with a reduced SLAC variant lacking the $\mathrm{Cu}_{\mathrm{T} 1}$ center, a Tyr108 radical near the TNC forms rapidly. We have found that ascorbate reduces the Tyr $108^{\circ}$ radical in wild-type SLAC about 10 times faster than it reacts with the $\mathrm{Cu}_{\mathrm{T} 1}{ }^{2+}$ center, possibly owing to radical transfer along a Tyr/Trp chain. Aerobic oxidation of two reduced SLAC mutants (Y108F and W132F) leads to the formation of a long-lived ( 15 min) Tyr radical with distinct absorption at $408 \mathrm{~nm}$. The diffusion of redox equivalents away from the primary enzymatic pathway in SLAC may indicate a poorly optimized enzyme or a mechanism to protect against protein damage.

File list (2)

SLACcom_chemrxiv.pdf (593.52 KiB)

view on ChemRxiv - download file

SLAC_SI_chemrxiv.pdf (1.36 MiB)

view on ChemRxiv - download file 


\title{
Does tyrosine protect $S$. coelicolor laccase from oxidative degrada- tion?
}

\author{
Patrycja J. Kielb ${ }^{\dagger}$, Harry B. Gray*, Jay R. Winkler* \\ Beckman Institute, California Institute of Technology, Pasadena CA 91125, United States
}

Supporting Information Placeholder

\begin{abstract}
We have investigated the roles of tyrosine (Tyr) and tryptophan (Trp) residues in the four-electron reduction of oxygen catalyzed by Streptomyces coelicolor laccase (SLAC). During normal enzymatic turnover in laccases, reducing equivalents are delivered to a type $1 \mathrm{Cu}$ center $\left(\mathrm{Cu}_{\mathrm{T} 1}\right)$ and then are transferred over $13 \AA$ to a trinuclear $\mathrm{Cu}$ site (TNC: $\left.\left(\mathrm{Cu}_{\mathrm{T} 3}\right)_{2} \mathrm{Cu}_{\mathrm{T} 2}\right)$ where $\mathrm{O}_{2}$ reduction occurs. The TNC in SLAC is surrounded by a large cluster of Tyr and Trp residues that can provide reducing equivalents when the normal flow of electrons is disrupted. Canters and coworkers have shown that when $\mathrm{O}_{2}$ reacts with a reduced SLAC variant lacking the $\mathrm{Cu}_{\mathrm{T} 1}$ center, a Tyr $108^{\bullet}$ radical near the TNC forms rapidly. We have found that ascorbate reduces the Tyr $108^{\bullet}$ radical in wild-type SLAC about 10 times faster than it reacts with the $\mathrm{Cu}_{\mathrm{T}}{ }^{2+}$ center, possibly owing to radical transfer along a Tyr/Trp chain. Aerobic oxidation of two reduced SLAC mutants (Y108F and W132F) leads to the formation of a long-lived ( $15 \mathrm{~min}) \mathrm{Tyr}^{\bullet}$ radical with distinct absorption at $408 \mathrm{~nm}$. The diffusion of redox equivalents away from the primary enzymatic pathway in SLAC may indicate a poorly optimized enzyme or a mechanism to protect against protein damage.
\end{abstract}

Multicopper oxidases (MCOs) efficiently utilize the thermodynamic potential of $\mathrm{O}_{2}$ to oxidize a variety of organic and inorganic substrates. The enzymes contain four copper atoms: a type $1 \mathrm{Cu}$ $\left(\mathrm{Cu}_{\mathrm{T} 1}\right.$, His, Met, Cys ligation); a trinuclear cluster (TNC) containing a binuclear $\mathrm{Cu}\left(\mathrm{Cu}_{\mathrm{T} 3}\right.$, His ligation); and a type $2 \mathrm{Cu}\left(\mathrm{Cu}_{\mathrm{T} 2}\right.$, His ligation) (Figure 1A). ${ }^{1-3}$ In the canonical MCO reaction mechanism, four-electron oxygen reduction proceeds at the TNC with reducing equivalents delivered from substrates via $\mathrm{Cu}_{\mathrm{T} 1} \cdot{ }^{2,4,5}$ Investigations of the small laccase (SLAC) from Streptomyces coelicolor revealed that a TNC-proximal tyrosine (Tyr108) is oxidized during catalysis. Interestingly, Canters and coworkers suggested that the radical intermediate, Tyr $108^{\bullet}$, might protect the enzyme from oxidative degradation. ${ }^{6,7}$ Of relevance here is our suggestion of a similar role for chains of tyrosine and tryptophan residues in enzymes that generate high-potential reactive intermediates. ${ }^{8-10}$

The kinetically challenging task of reducing oxygen to water requires delivery of four electrons and four protons in a well-coordinated manner. As incomplete $\mathrm{O}_{2}$ reduction often produces reactive oxygen species (ROS) that can be harmful to living cells, oxidases and oxygenases have evolved mechanisms to manage that risk. A case in point is the protection mechanism associated with oxygen reduction by cytochrome $c$ oxidase $(\mathrm{CcO}),{ }^{11-13}$ an enzyme with two $\mathrm{Cu}$ active sites $\left(\mathrm{Cu}_{\mathrm{A}}, \mathrm{Cu}_{\mathrm{B}}\right)$ and two hemes (heme $a$, heme $\left.a_{3}\right)$. Oxygen reduction proceeds at a coupled binuclear metal center (BNC, $\mathrm{Cu}_{\mathrm{B}}$-heme $a_{3}$ ) using electrons delivered from cytochrome $c$ to the
$\mathrm{BNC}$ via $\mathrm{Cu}_{\mathrm{A}}$ and heme $a$. Molecular oxygen binds to the reduced $\mathrm{BNC}$ and formation of the next intermediate depends on the redox states of $\mathrm{Cu}_{\mathrm{A}}$ and heme $a .^{12}$ If $\mathrm{O}_{2}$ binds to a fully reduced enzyme, the metal centers provide the four electrons to the bound $\mathrm{O}_{2}$ molecule. If, however, $\mathrm{O}_{2}$ binds to an enzyme in which only the $\mathrm{BNC}$ is reduced, the metal centers cannot provide the necessary reducing equivalents. In that case, heme $a_{3}$ provides 2 electrons, $\mathrm{Cu}_{\mathrm{B}}$ delivers one, and the fourth electron is delivered by a nearby tyrosine residue (Tyr244, bovine numbering), thereby avoiding production of ROS by incomplete $\mathrm{O}_{2}$ reduction.

SLAC is at even greater risk than $\mathrm{CcO}$, as it belongs to the family of MCOs that catalyze the aerobic oxidation of phenolic compounds involved in microbial lignin degradation. ${ }^{14-16}$ The powerfully oxidizing copper enzyme is a homotrimer in which each monomer is comprised of two cupredoxin structural domains (Figure 1A). ${ }^{17-20}$ Tyr108, which may function in a protective role, is conserved among all two-domain laccases, as well as in the mammalian protein ceruloplasmin. ${ }^{7}$ As Tyr108 is buried in the protein interior, reduction of a radical intermediate at this site would require intraprotein electron transfer from $\mathrm{Cu}_{\mathrm{T} 1}$ or hole hopping though Trp/Tyr chains to a reductant at the surface. We have investigated Tyr radical generation in wild-type and three mutant forms of SLAC following reaction of the reduced enzyme with $\mathrm{O}_{2}$.

We used the web based eMap application (see SI) to identify two paths through Tyr/Trp chains originating from Tyr108 in SLAC: one involving W132; the other W284 (Fig. 1B). ${ }^{21,22}$ The paths, which consist of residues positioned $<10 \AA$ from one another, lead to at least one surface-exposed residue. To explore these potential hole-transfer pathways, we prepared wild-type (WT) SLAC and three variants: Y108F, W132F and W284F. The Y108F mutant was designed to probe the effect of inactivation of both redox chains; and $\mathrm{W} 132 \mathrm{~F}$ and $\mathrm{W} 284 \mathrm{~F}$ were picked to explore the consequences of blocking these chains. Detailed descriptions of the protocols for protein expression and purification; site-directed mutagenesis; metal incorporation; and metal content analysis are in Supporting Information. The catalytic activities of all variants were assessed using a Michaelis-Menten (MM) kinetics model with 2,2'-azinobis(3-ethylbenzothiazoline-6-sulfonic acid $\left(\mathrm{ABTS}^{2-}\right)$ as substrate (see SI). All variants proved to be active with only modest variations in catalytic parameters. Since MM oversimplifies dual-substrate MCO catalysis, we were not able to draw detailed mechanistic conclusions from the derived kinetics parameters; instead, we used the analysis to make comparisons to published SLAC kinetics data (see SI). 


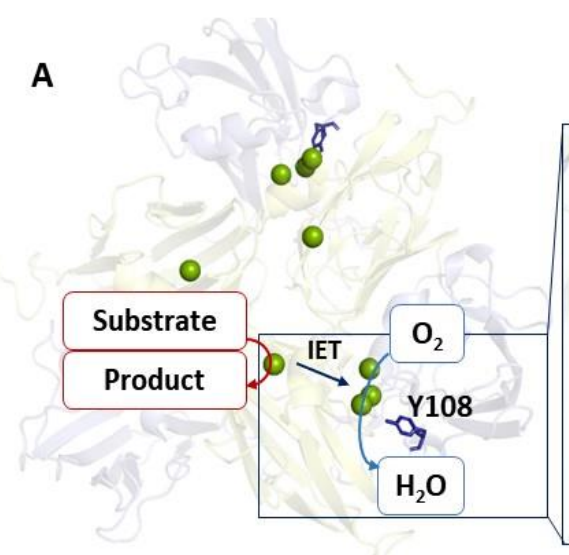

B
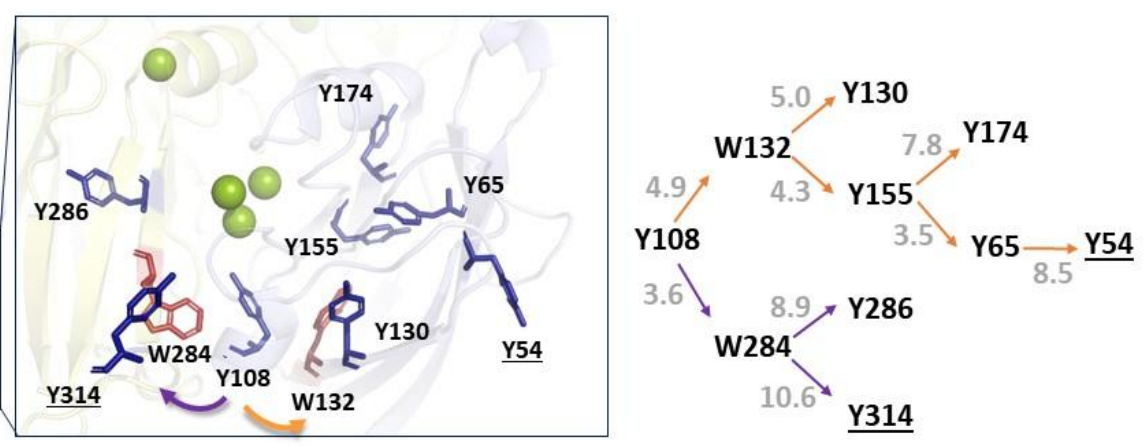

Figure 1. (A) Structure of small laccase (SLAC) PDB ID 3CG8 with copper ions and Tyr108 marked in green and blue, respectively. Substrate oxidation coupled to oxygen reduction is shown schematically. (B) Possible redox Tyr/Trp pathways: (I) Y108 $\rightarrow$ W284 $\rightarrow$ Y286/Y314, (II) Y108 $\rightarrow$ W132 $\rightarrow$ Y130/Y155 $\rightarrow$ Y65 $\rightarrow$ Y174/Y54, indicated by the purple and orange arrows, respectively. Numbers refer to shortest atom-atom distances in $\AA$.

SLAC UV-vis absorption spectra collected under single-oxygen turnover conditions are shown in Figure 2 and SI. Following manual addition of $\leq 1$ equivalent of $\mathrm{O}_{2}$ to fully reduced samples, a 583$\mathrm{nm}$ absorption peak appears immediately $(<1 \mathrm{~s})$ in the spectra of all four enzymes. An additional absorption maximum appears at 424 $\mathrm{nm}$ in the WT and W284F enzymes, and at $408 \mathrm{~nm}$ in Y108F and W132F. The 583-nm S288(Cys) $)_{\pi} \rightarrow \mathrm{Cu}_{\mathrm{T} 1}{ }^{2+}$ charge-transfer absorption is diagnostic of rapid $\mathrm{Cu}_{\mathrm{T} 1}$ oxidation. Among MCOs, the 408/424-nm absorptions have been observed previously only in the spectra of SLAC. ${ }^{6,7}$ We suggest that the peak at $424 \mathrm{~nm}$ is the optical signature of the Tyr $108^{\bullet}$ radical; and, notably, EPR measurements have shown that $\mathrm{Tyr} 108^{\bullet}$ is ferromagnetically coupled to $\mathrm{Cu}_{\mathrm{T} 2}$, producing a biradical triplet state. ${ }^{6}$ The $424-\mathrm{nm}$ feature is slightly red-shifted from the absorption peaks of Tyr radicals in other enzymes (ribonucleotide reductase Tyr122; $410 \mathrm{~nm} ;{ }^{23,24}$ DNA photolyase Tyr345, $408 \mathrm{~nm}^{25}$ ), possibly owing to Tyr108 interaction with $\mathrm{Cu}_{\mathrm{T} 2}$. The 408-nm features in the spectra of $\mathrm{Y} 108 \mathrm{~F}$ and W132F likely arise from Tyr radicals other than Tyr $108^{\bullet}$.

The time dependences of the aforementioned absorption features under single-oxygen turnover conditions are shown in Figure 3. Using the $\mathrm{Cu}_{\mathrm{T} 1}$ 583-nm extinction coefficient $\left(4400 \mathrm{M}^{-1} \mathrm{~cm}^{-1}\right.$ per $\mathrm{Cu}_{\mathrm{T} 1}$ site $)^{14}$ and an estimated value for $\operatorname{Tyr}^{\bullet}\left(2300 \mathrm{M}^{-1} \mathrm{~cm}^{-1}\right)^{26-28}$, we determined the concentrations of the two species relative to the amount of $\mathrm{O}_{2}$ that reacted with the enzyme. The initial concentrations of $\mathrm{Cu}_{\mathrm{T1}}{ }^{2+}$ and $\mathrm{Tyr}^{\bullet}$ add to approximately one molar equivalent of $\mathrm{O}_{2}$. In all four enzymes, the 583-nm absorption persists for several hundred seconds before returning to baseline as the $\mathrm{Cu}_{\mathrm{T} 1}{ }^{2+}$ center is reduced by excess ascorbate in solution. The $408 / 424 \mathrm{~nm}$ features exhibit strikingly different behavior. Stopped-flow measurements with the WT enzyme have shown that the 583-nm and 424$\mathrm{nm}$ signals appear in less than $50 \mathrm{~ms}\left(\left[\mathrm{O}_{2}\right]=0.13 \mathrm{mM}\right),{ }^{6}$ consistent with parallel formation of two species from a common precursor. Moreover, since the $\mathrm{Tyr}^{\bullet}$ reduction potential is substantially greater than that of $\mathrm{Cu}_{\mathrm{T} 1}$, the time constant for electron transfer between the two sites must be greater than 1s. In the WT enzyme, Tyr108 absorption decays monoexponentially with a time constanst of 27 $\mathrm{s}$; in the W284F mutant, the signal persists for longer and decays with a monoexponential time constant of $52 \mathrm{~s}$ (Fig. S3); also in $\mathrm{WT}, \mathrm{Cu}_{\mathrm{T} 1}{ }^{2+}$ absorption decreases only slightly as Tyr108 ${ }^{\bullet}$ decays, indicating that the two sites have distinct reduction pathways (Fig. 4). We suggest that Tyr $108^{\bullet}$ is reduced by ascorbate along Tyr/Trp redox chains (pathways 2 and 3 ) while $\mathrm{TNC} \mathrm{Cu}{ }^{2+}$ ions are reduced by ascorbate via $\mathrm{Cu}_{\mathrm{T} 1}$. In the $\mathrm{W} 284 \mathrm{~F}$ mutant, the $\mathrm{Cu}_{\mathrm{T} 1}{ }^{2+}$ signal in-

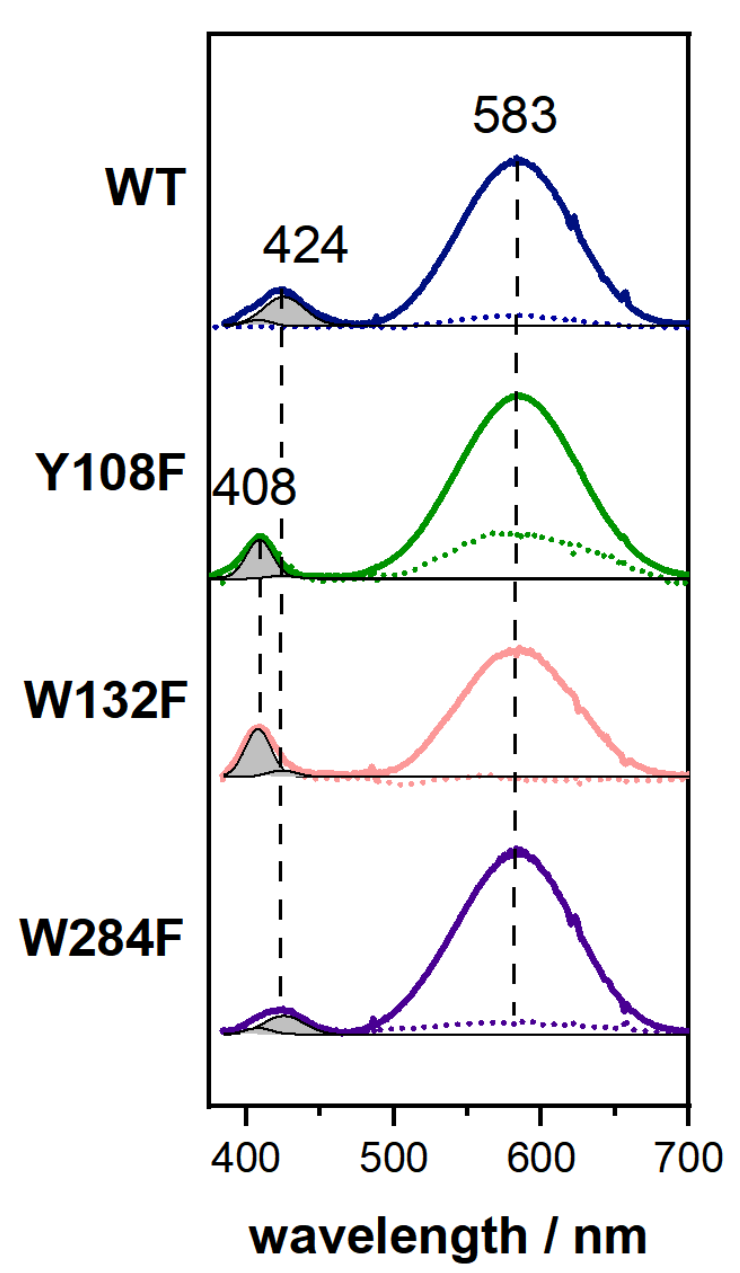

Figure 2. The baseline-corrected UV-vis spectra (A) of SLAC variants (from top to bottom: WT in navy blue, Y108F in green, $\mathrm{W} 132 \mathrm{~F}$ in light pink, W284F in purple) in deoxygenated $10 \mathrm{mM}$ phosphate buffer $\mathrm{pH} 7.5$ with excess of ascorbic acid, just after addition (1-2 s) of oxygenated buffer (solid line) and after reduction (1500 s) by ascorbate (dotted line). 
creases as the Tyr $108^{\bullet}$ signal decays, consistent with electron transfer from $\mathrm{Cu}_{\mathrm{Tl}}{ }^{+}$to Tyr108 (pathway 1 on Fig. 4). The Tyr ${ }^{\bullet}$ signals in the Y108F and W132 mutants, however, exhibit strikingly different behavior: both radicals persist for more than $15 \mathrm{~min}$, surviving much longer than $\mathrm{Cu}_{\mathrm{T} 1}^{2+}$ (Fig. S4). This observation indicates that the $\mathrm{Y} 108 \mathrm{~F}$ and $\mathrm{W} 132 \mathrm{~F}$ radicals are resistant to reduction both by ascorbate in solution and $\mathrm{Cu}_{\mathrm{Tl}}{ }^{+}$, as well as (presumably) by reduced

TNC.

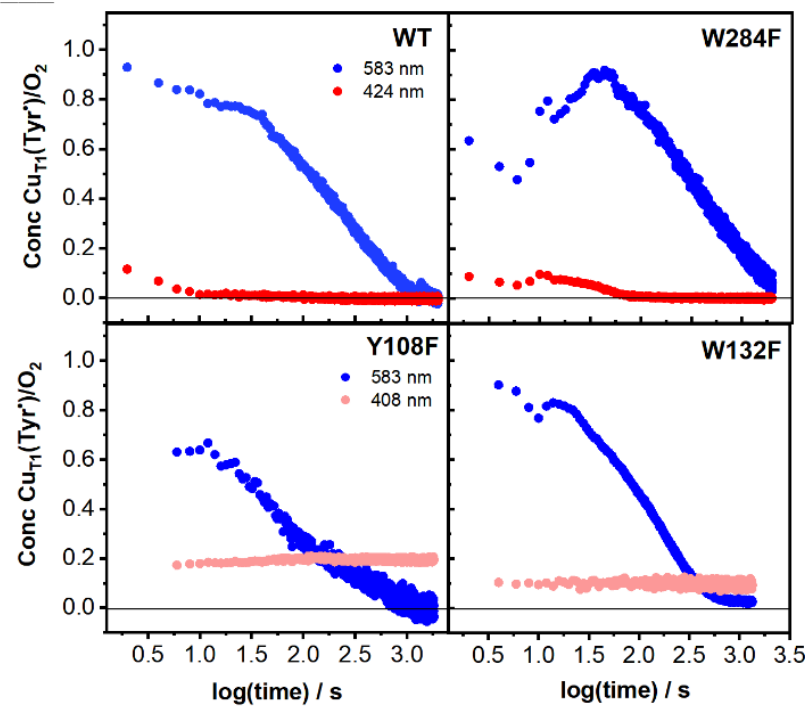

Figure 3. Comparison of time traces of concentrations of SLAC-variant intermediates from steady-state experiments. Spectral intensities of $583 \mathrm{~nm}$ and either $424 \mathrm{~nm}$ or $407 \mathrm{~nm}$ peaks, converted to concentrations and divided by the concentration of added $\mathrm{O}_{2}$, are shown as blue and red or orange dots, respectively.

We examined the newly formed $\mathrm{W} 132 \mathrm{~F}$ radical species by EPR spectroscopy, following an approach used by Tepper et al. ${ }^{6}$ in which $\mathrm{Cu}_{\mathrm{T} 1}$ is depleted, thereby providing a clearer signal of SLAC

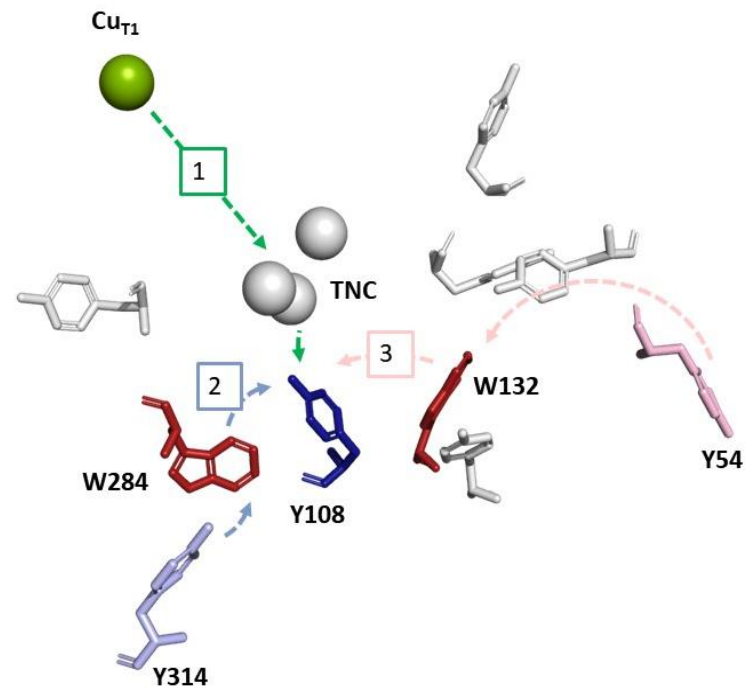

Figure 4. Proposed reduction pathways of Tyr108 in SLAC: 1) internal ET from $\mathrm{Cu}_{\mathrm{T} 1}$ through $\left.\mathrm{TNC}, 2\right) \mathrm{Tyr} / \mathrm{Trp}$ redox chain from surface-exposed Y314 residue through W284 residue and 3) Tyr/Trp redox chain from surface-exposed Y54 residue through W132. unpaired spins. Unfortunately, X-band EPR spectra of T1D W132F were not sufficiently intense to allow a definitive assignment of the SLAC organic radical. But since the spectrum closely resembles the EPR signal of T1D Y108F reported by Gupta et al., ${ }^{7}$ it could arise from the same radical (see Fig. S4). Gupta et al. suggested that the radical might originate from W284, ${ }^{7}$ although the $408-\mathrm{nm}$ absorption suggests Tyr is a more likely candidate. We can exclude Y108, as the EPR signal rules out a biradical triplet state. We think the signal could be due to Y130 or Y155, as both are part of the W132 path.

During SLAC catalyzed steady-state aerobic oxidation of ascorbate, a Tyr ${ }^{\bullet}$ signal gradually appears in the absorption spectrum of the WT enzyme. ${ }^{6}$ Our single-turnover data reveal, however, that ascorbate reduces Tyr108 ${ }^{\circ}$ more than 10 times faster (see SI) than $\mathrm{Cu}_{\mathrm{T} 1}{ }^{2+}$, indicating that the $\mathrm{Tyr}^{\bullet}$ radical detected by Tepper et al. during steady-state turnover is not Tyr108 ${ }^{\circ}$. It is possible that the persistent radical found in single-turnover experiments with $\mathrm{Y} 108 \mathrm{~F}$ and W132F enzymes forms in parallel with Tyr $108^{\bullet}$, albeit in lower yield, and this Tyr residue is responsible for the $410-430 \mathrm{~nm}$ spectral features observed in steady-state experiments. The large cluster of Tyr and Trp residues surrounding the TNC in SLAC provides a reservoir of electrons to enable hole migration away from the metal centers. Indeed, that a mutant enzyme lacking both $\mathrm{Y} 108$ and $\mathrm{Cu}_{\mathrm{T} 2}$ retains $>20 \%$ of wild-type activity indicates multiple donors are available in SLAC to deliver electrons to $\mathrm{O}_{2}{ }^{29}$

Multicopper oxidases face challenges similar to those encountered by $\mathrm{CcO}$. It is not clear at present whether the leakage of oxidizing equivalents away from the primary enzymatic pathway is evidence of a poorly optimized enzyme or a clever mechanism to protect against damage to the protein. As the TNC can transfer just three electrons to $\mathrm{O}_{2}$, ROS will be produced unless an electron is delivered rapidly from a well coupled redox site in the protein. In the consensus mechanism, ${ }^{1,2}$ the distant $(\sim 13 \AA) \mathrm{Cu}_{\mathrm{T} 1}$ furnishes the fourth electron, but evidence indicates the reaction from that copper to the TNC cannot keep up with the rate of water production. We conclude that Tyr108, which is oxidized very rapidly during SLAC turnover, functions as the protective reductant. When Tyr108 is not available, additional Tyr residues pitch in to prevent incomplete $\mathrm{O}_{2}$ reduction.

\section{ASSOCIATED CONTENT}

\section{Supporting Information}

Protein expression and purification, metal content analysis, site-directed mutagenesis details, the use of electron transfer map eMap, steady-state Michaelis-Menten kinetics, single oxygen turnover by SLAC variants experiments and EPR experiments are included in Supporting Information. The Supporting Information is available free of charge on the ACS Publications website.

\section{AUTHOR INFORMATION}

\section{Corresponding Author}

Correspondence should be addressed to:

Harry B. Gray hbgray@caltech.edu

Jay R. Winkler winklerj@ caltech.edu

\section{Present Addresses}

$\uparrow$ Institute of Chemistry, University of Potsdam, Karl-LiebknechtStr. 24-25, 14476 Potsdam-Golm, Germany

\section{Notes}

The authors declare no competing financial interests. 


\section{ACKNOWLEDGMENT}

We thank Paul Oyala for assistance with EPR experiments and Yuling Sheng for help with protein expression and purification. Research reported in this publication was supported by the National Institute of Diabetes and Digestive and Kidney Diseases of the National Institutes of Health under Award Number R01DK019038. The content is solely the responsibility of the authors and does not necessarily represent the official views of the National Institutes of Health. Additional support was provided by the Arnold and Mabel Beckman Foundation.

\section{REFERENCES}

(1) Solomon, E. I.; Heppner, D. E.; Johnston, E. M.; Ginsbach, J. W.; Cirera, J.; Qayyum, M.; Kieber-Emmons, M. T.; Kjaergaard, C. H.; Hadt, R. G.; Tian, L. Copper Active Sites in Biology. Chem. Rev. 2014, 114 (7), 3659-3853. https://doi.org/10.1021/cr400327t.

(2) Jones, S. M.; Solomon, E. I. Electron Transfer and Reaction Mechanism of Laccases. Cell. Mol. Life Sci. 2015, 72 (5), 869-883. https://doi.org/10.1007/s00018-014-1826-6.

(3) Sekretaryova, A.; Jones, S. M.; Solomon, E. I. $\mathrm{O}_{2}$ Reduction to Water by High Potential Multicopper Oxidases: Contributions of the T1 Copper Site Potential and the Local Environment of the Trinuclear Copper Cluster. J. Am. Chem. Soc. 2019, 141 (28), 11304-11314. https://doi.org/10.1021/jacs.9b05230.

(4) Farver, O.; Tepper, A. W. J. W.; Wherland, S.; Canters, G. W.; Pecht, I. Site-Site Interactions Enhances Intramolecular Electron Transfer in Streptomyces Coelicolor Laccase. J. Am. Chem. Soc. 2009, 131 (51), 18226-18227. https://doi.org/10.1021/ja908793d.

(5) Wherland, S.; Miyazaki, K.; Pecht, I. Intramolecular Electron Transfer in the Bacterial Two-Domain Multicopper Oxidase MgLAC. $\begin{array}{llll}\text { Biochemistry 2016, } & 55 & \text { (21), } & \text { 2960-2966. }\end{array}$ https://doi.org/10.1021/acs.biochem.6b00158.

(6) Tepper, A. W. J. W.; Milikisyants, S.; Sottini, S.; Vijgenboom, E.; Groenen, E. J. J.; Canters, G. W. Identification of a Radical Intermediate in the Enzymatic Reduction of Oxygen by a Small Laccase. J. Am. Chem. Soc. 2009, 131 (33), 11680-11682. https://doi.org/10.1021/ja900751c.

(7) Gupta, A.; Nederlof, I.; Sottini, S.; Tepper, A. W. J. W.; Groenen, E. J. J.; Thomassen, E. A. J.; Canters, G. W. Involvement of Tyr108 in the Enzyme Mechanism of the Small Laccase from Streptomyces Coelicolor. J. Am. Chem. Soc. 2012, 134 (44), 18213-18216. https://doi.org/10.1021/ja3088604.

(8) Gray, H. B.; Winkler, J. R. Hole Hopping through Tyrosine/Tryptophan Chains Protects Proteins from Oxidative Damage. Proc. Natl. Acad. Sci. U. S. A. 2015, 112 (35), 10920-10925. https://doi.org/10.1073/pnas.1512704112.

(9) Winkler, J. R.; Gray, H. B. Could Tyrosine and Tryptophan Serve Multiple Roles in Biological Redox Processes? Philos. Trans. A. Math. Phys. Eng. Sci. 2015, 373 (2037), 20140178. https://doi.org/10.1098/rsta.2014.0178.

(10) Gray, H. B.; Winkler, J. R. The Rise of Radicals in Bioinorganic Chemistry. Isr. J. Chem. 2016, 56 (9-10), 640-648. https://doi.org/10.1002/ijch.201600069.

(11) Babcock, G. T. How Oxygen Is Activated and Reduced in Respiration. Proc. Natl. Acad. Sci. U. S. A. 1999, 96 (23), 12971-12973. https://doi.org/10.1073/pnas.96.23.12971.

(12) Wikström, M.; Krab, K.; Sharma, V. Oxygen Activation and Energy Conservation by Cytochrome c Oxidase. Chem. Rev. 2018, 118 (5), 2469-2490. https://doi.org/10.1021/acs.chemrev.7b00664.

(13) Blomberg, M. R. A. Mechanism of Oxygen Reduction in Cytochrome c Oxidase and the Role of the Active Site Tyrosine. $\begin{array}{lllll}\text { Biochemistry 2016, } & 55 & \text { (3), } & \text { 489-500. }\end{array}$ https://doi.org/10.1021/acs.biochem.5b01205.
(14) Majumdar, S.; Lukk, T.; Solbiati, J. O.; Bauer, S.; Nair, S. K.; Cronan, J. E.; Gerlt, J. A. Roles of Small Laccases from Streptomyces in Lignin Degradation. Biochemistry 2014, 53 (24), 4047-4058. https://doi.org/10.1021/bi500285t.

(15) Riva, S. Laccases: Blue Enzymes for Green Chemistry. Trends Biotechnol. 2006, 24 (5), 219-226. https://doi.org/10.1016/j.tibtech.2006.03.006.

(16) Abdel-Hamid, A. M.; Solbiati, J. O.; Cann, I. K. O. Insights into Lignin Degradation and Its Potential Industrial Applications; Elsevier, 2013; Vol. 82. https://doi.org/10.1016/B978-0-12-407679-2.00001-6.

(17) Machczynski, M. C.; Vijgenboom, E.; Samyn, B.; Canters, G. W. Characterization of SLAC: A Small Laccase from Streptomyces Coelicolor with Unprecedented Activity. Protein Sci. 2004, 13 (9), 23882397. https://doi.org/Doi 10.1110/Ps.04759104.

(18) Skálová, T.; Dohnálek, J.; Ostergaard, L. H.; Ostergaard, P. R.; Kolenko, P.; Dusková, J.; Hasek, J. Crystallization and Preliminary X-Ray Diffraction Analysis of the Small Laccase from Streptomyces Coelicolor. Acta Crystallogr. Sect. F. Struct. Biol. Cryst. Commun. 2007, 63 (Pt 12), 1077-1079. https://doi.org/10.1107/S1744309107060721.

(19) Skálová, T.; Dohnálek, J.; Østergaard, L. H.; Østergaard, P. R.; Kolenko, P.; Dušková, J.; Štěpánková, A.; Hašek, J. The Structure of the Small Laccase from Streptomyces Coelicolor Reveals a Link between Laccases and Nitrite Reductases. J. Mol. Biol. 2009, 385 (4), 1165-1178. https://doi.org/10.1016/j.jmb.2008.11.024.

(20) Skálová, T.; Dušková, J.; Hašek, J.; Štěpánková, A.; Kova, T.; Østergaard, L. H.; Dohnálek, J. Structure of Laccase from Streptomyces Coelicolor after Soaking with Potassium Hexacyanoferrate and at an Improved Resolution of $2.3 \AA$. Acta Crystallogr. Sect. F Struct. Biol. Cryst. Commun. 2011, 67 (1), 27-32 https://doi.org/10.1107/S1744309110046099.

(21) Tazhigulov, R. N.; Gayvert, J. R.; Wei, M.; Bravaya, K. B. EMap: A Web Application for Identifying and Visualizing Electron or Hole Hopping Pathways in Proteins. J. Phys. Chem. B 2019, 123 (32), 69466951. https://doi.org/10.1021/acs.jpcb.9b04816.

(22) Beratan, D. N.; Betts, J. N.; Onuchic, J. N. Protein Electron Transfer Rates Set by the Bridging Secondary and Tertiary Structure. Science (80-. ). 1991, $252 \quad$ (5010), 1285-1288. https://doi.org/10.1126/science.1656523.

(23) Minnihan, E. C.; Nocera, D. G.; Stubbe, J. Reversible, LongRange Radical Transfer in E. Coli Class Ia Ribonucleotide Reductase. Acc. Chem. Res. 2013, 46 (11), 2524-2535. https://doi.org/10.1021/ar4000407.

(24) Lam, K. Y.; Govindaraju, K.; Han, J. Y.; Salmon, G. A.; Sykes, A. G. Free-Radical Formation in the Pulse-Radiolysis Oxidation of Inactive Escherichia Coli Met-R2 Ribonucleotide Reductase. J. Chem. Soc. Dalt. Trans. 1993, No. 18, 2797-2801. https://doi.org/10.1039/DT9930002797.

(25) Müller, P.; Ignatz, E.; Kiontke, S.; Brettel, K.; Essen, L. O. SubNanosecond Tryptophan Radical Deprotonation Mediated by a ProteinBound Water Cluster in Class II DNA Photolyases. Chem. Sci. 2018, 9 (5), 1200-1212. https://doi.org/10.1039/c7sc03969g.

(26) Solar, S.; Solar, W.; Getoff, N. Reactivity of OH with Tyrosine in Aqueous Solution Studied by Pulse Radiolysis. J. Phys. Chem. 1984, 88 (10), 2091-2095. https://doi.org/10.1021/j150654a030.

(27) Weinstein, M.; Alfassi, Z. B.; DeFelippis, M. R.; Klapper, M. H.; Faraggi, M. Long Range Electron Transfer between Tyrosine and Tryptophan in Hen Egg-White Lysozyme. Biochim. Biophys. Acta (BBA)/Protein Struct. Mol. 1991, $1076 \quad$ (2), 173-178. https://doi.org/10.1016/0167-4838(91)90262-X.

(28) Stubbe, J.; Donk, W. a Van Der. Protein Radicals in Enzyme Catalysis. Chem. Rev. 1998, 98 (2), 705-762. https://doi.org/10.1021/cr9400875.

(29) Gupta, A. Unraveling the Mechanism of Multicopper Oxidases: From Ensemble to Single Molecule, Ph.D. Thesis, Leiden University, 2014. 
Formation of Tyr radical during oxygen turnover in S. coelicolor laccase and subsequent hole transfer through chains composed of Tyr and Trp residues.

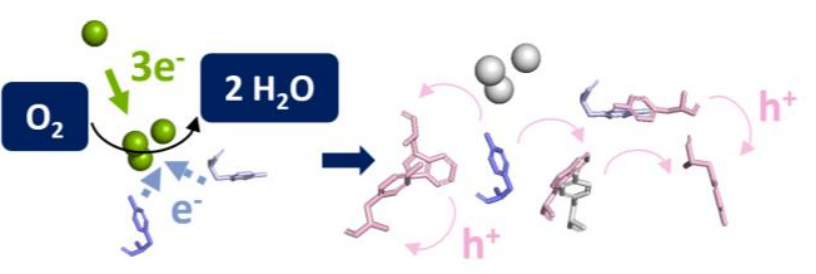

Insert Table of Contents artwork here 
Supporting information belonging to the manuscript

\title{
Does tyrosine protect $S$. coelicolor laccase from oxidative degradation?
}

\author{
Patrycja J. Kielb†, Harry B. Gray*, Jay R. Winkler* \\ Beckman Institute, California Institute of Technology, Pasadena CA 91125, United States
}

\section{Content}

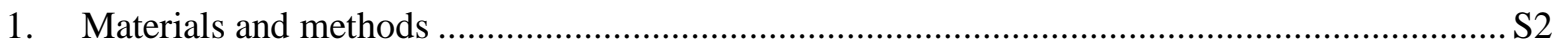

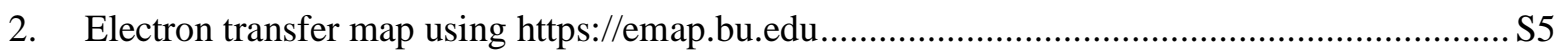

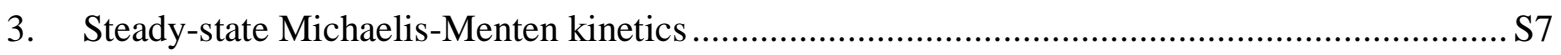

4. Single oxygen turnover experiments involving SLAC variants........................................... S10

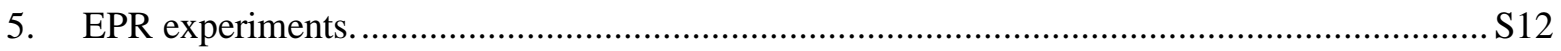




\section{Materials and methods}

Protein expression and purification:

The SLAC gene of Streptomyces coelicolor encodes 343 amino acids, but in matured form lacks residues 1-45. ${ }^{1}$ A custom-made pET28b(+) vector containing genes encoding HisTag sequence, thrombin-cleavage site (H H H H H H S S G L V P R G S H) followed by a truncated version (tSLAC) of the protein (45-343 residues) was purchased from Biomatik Corporation (www.biomatik.com). The lyophilized plasmid was resuspended in EB buffer and diluted to a final concentration of $10 \mathrm{ng} / \mu \mathrm{L}$. The diluted $\mathrm{pET} 28 \mathrm{~b}(+)$ strain was transformed into competent NovaBlue cells, which were subsequently grown overnight at $37^{\circ} \mathrm{C}$. The next day, single colonies were chosen for inoculation $\left(12-16 \mathrm{~h}\right.$ at $37^{\circ} \mathrm{C}$, shaking at $\left.250 \mathrm{RPM}\right)$ in $5 \mathrm{~mL}$ of LB media supplemented with kanamycin antibiotic at a concentration of $50 \mu \mathrm{g} / \mathrm{mL}$. After cells were grown, the DNA was extracted and purified using a MiniPrep kit from Millipore. After DNA verification, the plasmid solutions were used for transformation into BL21 (DE3) cells. Cells were distributed into a Petri dish containing LB medium supplemented with kanamycin antibiotic and were incubated overnight (12$16 \mathrm{~h}$ ) at $37^{\circ} \mathrm{C}$, shaking at $250 \mathrm{RPM}$. The next day, single colonies were chosen for inoculation ( $\mathrm{ca} .6 \mathrm{~h}$ at $37{ }^{\circ} \mathrm{C}$, shaking at $250 \mathrm{RPM}$ ) in $5 \mathrm{~mL}$ of TB medium supplemented with kanamycin antibiotic. After that time, grown cells were transferred into 6-L Erlenmeyer flasks and further grown in 2L of autoclaved TB medium with kanamycin. The cells were grown at $30{ }^{\circ} \mathrm{C}$, shaking at $190 \mathrm{RPM}$ until an optical density at $600 \mathrm{~nm}\left(\mathrm{OD}_{600 \mathrm{~nm}}\right)$ reached a value of 0.6-1.0.

Protein expression was induced by adding $0.4 \mathrm{mM}$ of Isopropyl- $\beta$-D-1-thiogalactopyranoside (IPTG) to the cell media. At the same time, $0.6 \mathrm{mM}$ of $\mathrm{CuSO}_{4}$ was added to cell culture to induce SLAC metalation during folding, as shown in a similar protocol for of expression and metalation of CotA laccase by Durao et al. ${ }^{2}$ After $4 \mathrm{~h}$ of shaking at $170 \mathrm{RPM}\left(25^{\circ} \mathrm{C}\right)$, the cell culture was incubated at RT for another $20 \mathrm{~h}$ without shaking. Metal content analysis of purified expressed protein exhibited higher copper content ( 3.9 $\mathrm{Cu} /$ monomer) than that of protein in which $\mathrm{Cu}$ was incorporated via dialysis against copper salts after protein purification.

Cells were harvested by centrifugation. Pellets were resuspended in $10 \mathrm{mM}$ sodium phosphate buffer $\mathrm{pH}$ 7.5 with $250 \mathrm{mM} \mathrm{NaCl}$ and $10 \mathrm{mM}$ imidazole. Cell contents were released using sonication by applying six cycles of 5 min of repeated 1-s sonication and 1-s waiting time steps. During sonication, the protein solution was stored in an ice bath. The obtained lysate was centrifuged for $45 \mathrm{~min}$ at 12000 RPM to separate protein extracts from residual of the cell media. The supernatant was filtered through $0.22 \mathrm{~mm}$ filters. 
The filtrate was used as starting material in the three-step SLAC purification procedure. First, affinity chromatography with Ni-NTA beads was used to separate HisTag-SLAC from other proteins. The solution was loaded onto a washed and pre-equilibrated column with $10 \mathrm{mM}$ phosphate $\mathrm{pH} 7.5$ buffer containing $300 \mathrm{mM} \mathrm{NaCl}$ and $10 \mathrm{mM}$ imidazole. The bound protein was washed with equilibration buffer and then with a washing buffer containing $30 \mathrm{mM}$ of imidazole. The protein was eluted from the column using 10 $\mathrm{mM}$ phosphate pH 7.5 buffer containing $300 \mathrm{mM} \mathrm{NaCl}$ and $300 \mathrm{mM}$ imidazole. Eluted fractions with blue color, indicative of $\mathrm{Cu}_{\mathrm{T1}}{ }^{2+}$ of laccase, were collected and loaded onto $10 \mathrm{kDa}$ or $30 \mathrm{kDa}$ spin-filters, washed and centrifuged for multiple cycles until the concentration of imidazole decreased to $c a .30 \mathrm{mM}$. The concentrated protein solution was diluted with equilibration buffer and loaded onto a Ni-NTA column for the second time. The purification protocol, as described above, was repeated with the difference of washing buffer used, which contained $50 \mathrm{mM}$ imidazole in the second run. After elution, $\mathrm{NaCl}$ and imidazole were removed from the solution using spin-filters. The next step of purification employed FPLC anion exchange chromatography. ${ }^{3}$ The protein solution $(10 \mathrm{mM}$ phosphate $\mathrm{pH} 7.5)$ was loaded onto the pre-equilibrated (10 $\mathrm{mM}$ phosphate $\mathrm{pH}$ 7.5) diethylaminoethyl-Sepharose (HiTrap DEAE Sepharose FF $3 \times 5 \mathrm{~mL}$ column, GE HealthCare) column. The loaded protein was washed with the same buffer and eluted with a gradient of 0$500 \mathrm{mM} \mathrm{NaCl}$. The protein began to elute at ca. 100-200 mM NaCl and blue fractions were pooled. The protein concentration was assessed by UV-Vis spectroscopy determining the absorbance at $280 \mathrm{~nm}$ (GillHippel assay). ${ }^{4}$ The protein solution was stored at $-80^{\circ} \mathrm{C}$ in the presence of $20-30 \%$ of glycerol. Mass spectrometry indicated a mass of $32256 \mathrm{Da}$ (WT), which corresponds to His-TagSLAC protein without the last three residues (EPH). All other SLAC variants (W284F, W132F, and Y108F) were prepared in the same way.

\section{Metal content analysis:}

A modified BCA (bicinchoninic acid) assay was used to analyze copper content in purified samples. ${ }^{5,6}$ In the first step, the protein was denatured by mixing $30 \mu \mathrm{L}$ of $100 \mu \mathrm{M}$ of protein solution with $45 \mu \mathrm{L}$ of 10 $\mathrm{M}$ urea. The $\mathrm{pH}$ was adjusted to 3.5 with trichloroacetic acid to prevent the Biuret reaction. The solution was left overnight at RT. Subsequently, released copper ions from the protein were reduced by the addition of L-ascorbic acid. The BCA reagent (ThermoScientitc ${ }^{\mathrm{TM}}$ Pierce $\left.^{\mathrm{TM}}\right)^{7}$ was then added to the protein solution to chelate $\mathrm{Cu}^{1+}$ ions. The copper concentration was assessed by the absorbance of $\mathrm{Cu}$-BCA molecules at $568 \mathrm{~nm}$ in comparison to a previously prepared calibration curve. SLAC samples were found to house around 3.9 copper atoms per monomer.

Proper incorporation of copper ions into the protein matrix is an essential aspect of preserving laccase activity and its thermal stability, as shown for numerous laccases. Two-domain (2D) laccases (e.g., SLAC) 
differ from three-domain (3D) laccases in that they not only lack a third domain, but six His $\mathrm{N} \varepsilon$ atoms coordinate to $\mathrm{Cu}_{\mathrm{T} 3}$, rather than five $\mathrm{N} \varepsilon$ and one $\mathrm{N} \sigma$ as in $3 \mathrm{D}$-laccases. ${ }^{8}$ In 3D-laccases, this difference distinguishes the two $\mathrm{Cu}_{\mathrm{T} 3}$ atoms, and thus, they are referred to as $\mathrm{Cu}_{\mathrm{T} 3 \alpha}$, and $\mathrm{Cu}_{\mathrm{T} 3 \beta} .{ }^{9}$ 2D-laccases lack this distinction. Moreover, in 2D-laccases, the TNC cluster bridges two polypeptide monomers, so it is essential for the proper folding of protein's quaternary structure. Furthermore, Gabdulkhakov et al. ${ }^{8}$ have shown in the small laccase Ss11 from Streptomyces sviceus that 2D-laccases possess a narrower channel leading to $\mathrm{Cu}_{\mathrm{T} 2}$ than that in 3D-laccases. The narrow channel can result in greater difficulty filling $\mathrm{Cu}_{\mathrm{T} 2}$ site. They also had shown that a $\mathrm{Cu}_{\mathrm{T} 2}$ site could only be filled when cells were overexpressed in the presence of a high concentration $(1 \mathrm{mM})$ of copper salt. We observed similar behavior with SLAC. To ensure the proper incorporation of all copper atoms, copper ions must be present during folding of the protein to fully occupy the $\mathrm{Cu}_{\mathrm{T} 2}$ site before quaternary structure is formed.

Site-directed mutagenesis:

Primers for Y108F mutation:

Y108F-F 5'-CAC GGC CTG GAC TAC GAG ATC TCC AGC-3'

Y108F-R 5'-GCT GGA GAT CTC GAA GTC CAG GCC GTG-3'

Primers for W132F mutation:

W132F-F 5'-CGC ACC TAC ACC TTC CGC ACC CAC AAA C-3'

W132F-R 5'-G TTT GTG GGT GCG GAA GGT GTA GGT GCG-3'

Primers for W284F mutation:

W284F-F 5'-GGC GCC GGG GCG TTC ATG TAC CAC TGC-3'

W284F-R 5'-GCA GTG GTA CAT GAA CGC CCC GGC GCC-3'

Primers for C288S (T1D) mutation:

C288S-F 5' (TGG ATG TAC CAC AGC CAC GTC CAG AGC CAC)

C288S-R 5' (GTG GCT CTG GAC GTG GCT GTG GTA CAT CCA)

The last primers (C288S) were used to create a double mutant with $\mathrm{C} 288 \mathrm{~S}$ and W132F mutations.

DNA sequencing and mass spectroscopy confirmed successful site-directed mutagenesis of all SLAC variants. 


\section{Electron transfer map using https://emap.bu.edu}

We have used software (www.emap.bu.edu ${ }^{10}$ developed by the Bravaya group to identify possible ET pathways in SLAC. The computations were based on semiclassical electron-transfer theory ${ }^{11}$ and implemented with a Pathways model developed by D. Beratan and coworkers. ${ }^{12,13}$ The software generated an ET map employing all possible aromatic residues meeting a 'pairwise distance' criterion, based on the available crystal structure (pdb id: 3CG8). We focused on identifying possible pathways originating from the Y108 residue and obtained three possibilities shown below (Scheme S1- Scheme S3).

The representation of the first pathway Y108-W132-...-Y54 ending with surface-exposed Y54 residue is presented on Scheme S1. The shortest pathway includes residues Y108, W132, Y130, and Y54. Other possible ET routes include Y155, Y65, and Y174.
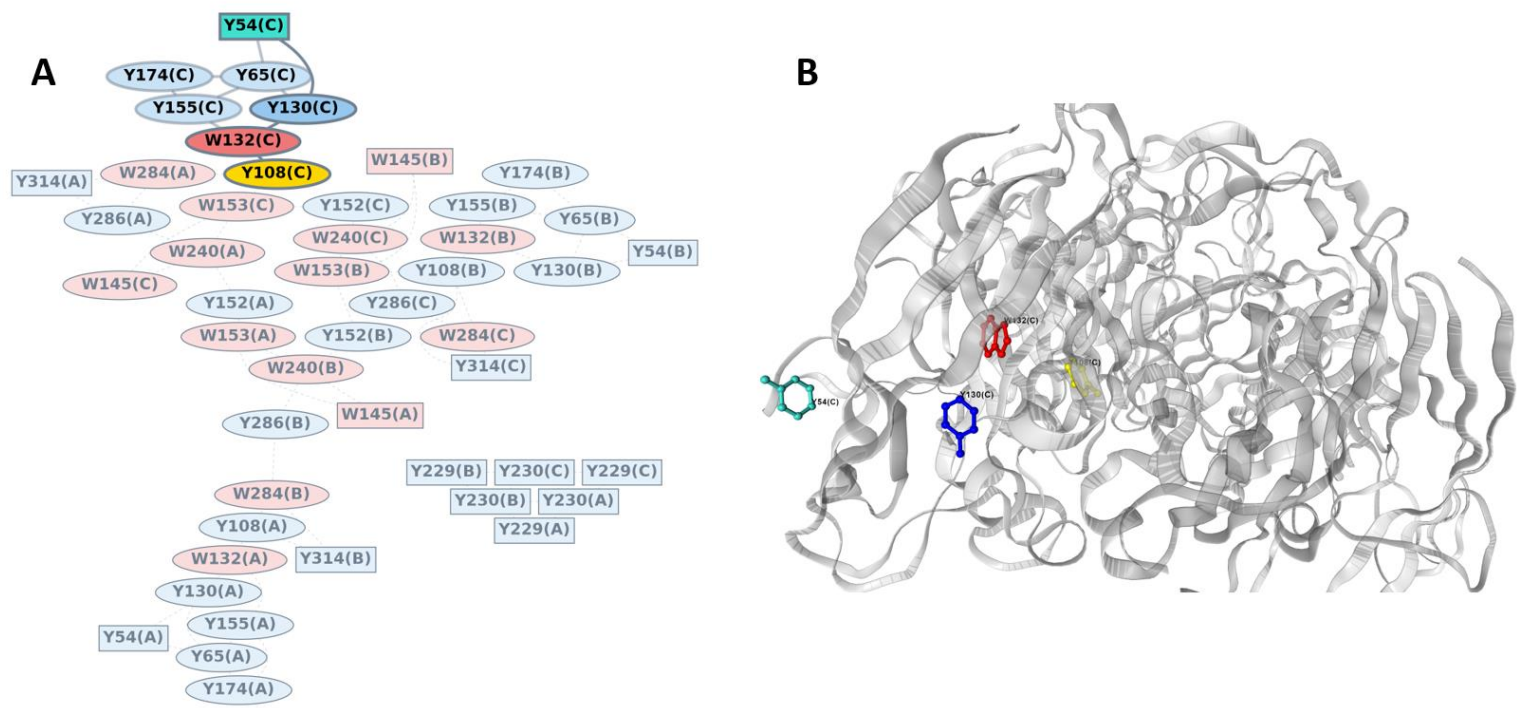

Scheme S1. ET map analysis generated by eMap software on SLAC structure (pdb id: $3 c \mathrm{cg}$ ). (A) The ET map representing all possible aromatic residues with the indicated shortest path from Y108 (chain C) to Y54 (chain C), marked in yellow and green, respectively. (B) The 3D structure of the analyzed ET pathway. 
The representation of the second pathway Y108-W284-...-Y314 ending with surface-exposed Y314 residue is presented on Scheme S2. The shortest pathway includes residues Y108, W284, (Y286), and Y314.
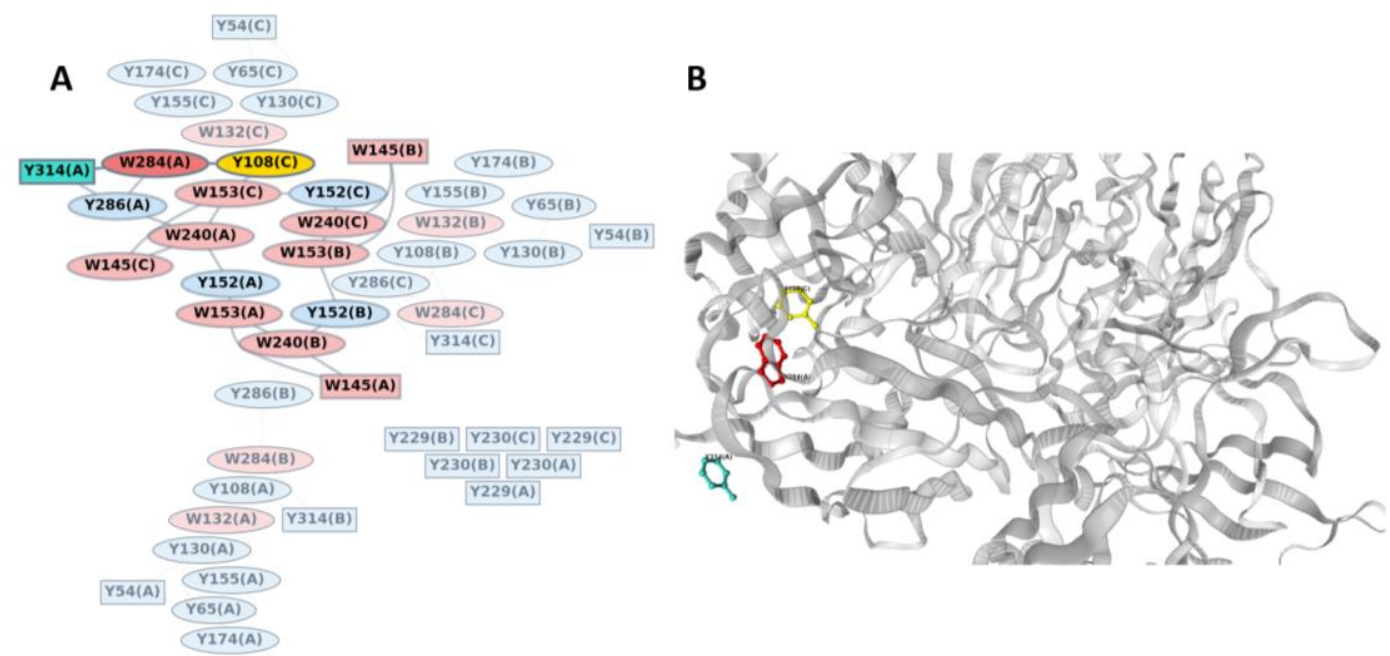

Scheme S2. ET map analysis generated by eMap software on SLAC structure (pdb id: $3 \operatorname{cg} 8$ ). (A) The ET map representing all possible aromatic residues with the indicated shortest path from Y108 (chain C) to Y314 (chain A), marked in yellow and green, respectively. (B) The 3D structure of the analyzed ET pathway.

The representation of the third pathway Y108-W153-...-W145 ending with surface-exposed W145 residue is presented on Scheme S3. The distance between Y108 and the second residue in the path (W153) is longer than $9 \AA$, which makes it less likely for the electron to be transferred via a hole hopping mechanism. Moreover, the path involves many more residues than previous ones, resulting in a relatively long path (37 $\AA$ A). On the basis on these consideratons, we excluded this pathway as a potential radical transfer route from Y108 to the protein surface. 

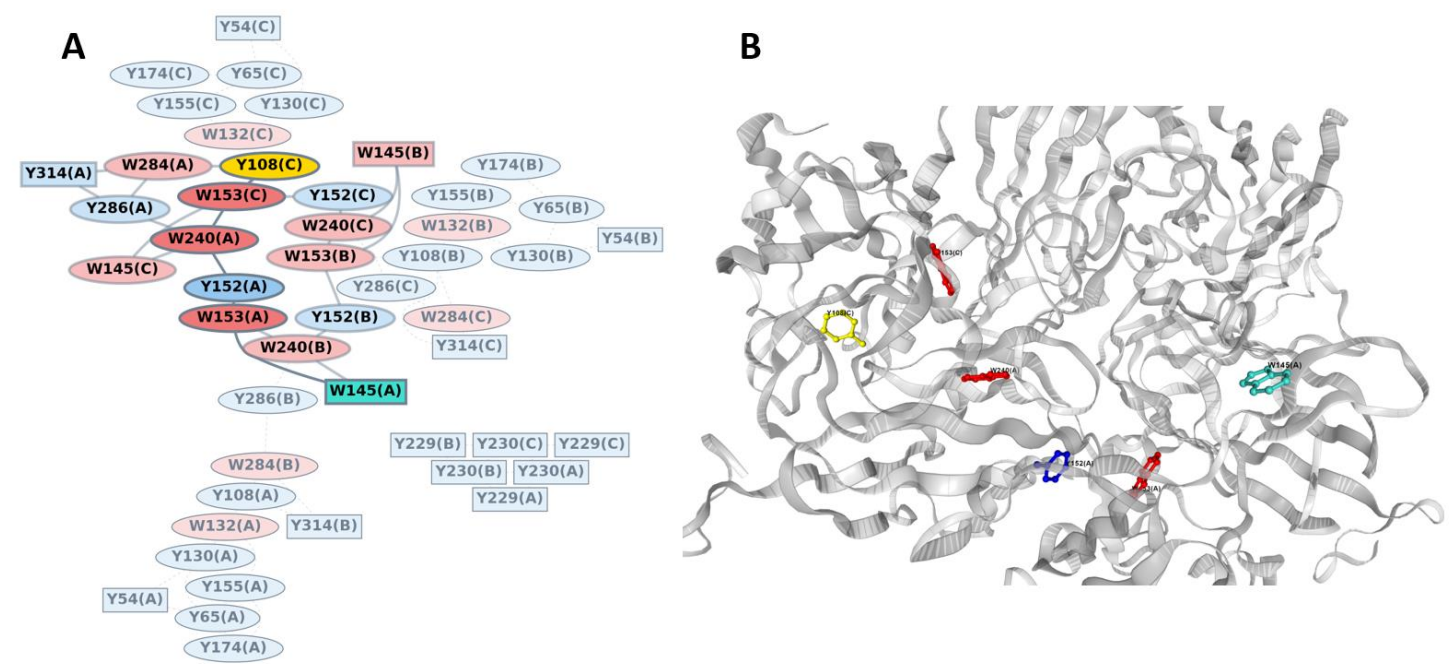

Scheme S3. ET map analysis generated by eMap software on SLAC structure (pdb id: $3 \operatorname{cg} 8$ ). (A) The ET map representing all possible aromatic residues with the indicated shortest path from Y108 (chain C) to Y145 (chain A), marked in yellow and green, respectively. (B) The 3D structure of the analyzed ET pathway.

\section{Steady-state Michaelis-Menten kinetics}

We performed steady-state Michaelis Menten kinetics experiments to assess the catalytic performance of WT and mutant SLAC enzymes. All measurements were performed using $100 \mathrm{mM}$ acetate buffer $\mathrm{pH} 4.5$ at $60^{\circ} \mathrm{C}$. Solutions were constantly stirred during measurements. We used $\mathrm{ABTS}^{2-}\left(2,2^{\prime}\right.$-azinobis [3ethylbenzothiazoline-6-sulfonic acid]-diammonium salt) as a substrate, which is a common substrate for establishing enzymatic activity of laccases ${ }^{14}$ and other oxidizing enzymes (e.g., HRP ${ }^{15}$ ). The concentration of $\mathrm{O}_{2}$ for all measurements was $c a .270 \mu \mathrm{M}$. One-electron oxidation of $\mathrm{ABTS}^{2-}$ forms a radical ABTS ${ }^{\bullet-}$ with distinct absorbance features at $420 \mathrm{~nm}$ and a broad band at 600-800 nm (Fig. S1). We have monitored a change in absorbance of $\mathrm{ABTS}^{\bullet-}$ at $420 \mathrm{~nm}\left(\varepsilon_{420}=36000 \mathrm{M}^{-1} \mathrm{~cm}^{-1}\right)$ in $100 \mu \mathrm{M}-10 \mathrm{mM} \mathrm{ABTS}^{2-}$ solutions as a function of time after the addition of $25 \mathrm{nM}$ SLAC. The observed time traces were corrected for uncatalyzed $\mathrm{ABTS}^{2-}$ oxidation by subtraction of a trace obtained in the absence of enzyme.

Initial enzymatic kinetic rates were calculated from obtained data and plotted against $\mathrm{ABTS}^{2-}$ concentration (Fig. S2). Data were fit to the Michaelis-Menten (MM) equation from which Michaelis-Menten constants $\left(\mathrm{K}_{\mathrm{m}}\right)$ and catalytic rate constants $\left(\mathrm{k}_{\mathrm{CAT}}\right)$ were calculated (Table $\left.\mathrm{S} 1\right)$. The simplistic representation of the Michaelis-Menten model describing SLAC kinetics is depicted in Scheme S4. It is interesting to note that

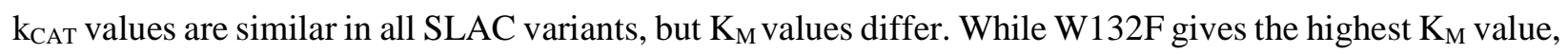
W284F gives the lowest $\mathrm{K}_{\mathrm{M}}$ value and the best performance, as its catalytic efficiency $\left(\mathrm{k}_{\mathrm{CAT}} / \mathrm{K}_{\mathrm{M}}\right)$ is 1.5 times higher than that for WT (Figure S2 and Table S1). Based on the MM model, it is reasonable to 
consider these changes as a result of either different rates of substrate binding $\left(\mathrm{k}_{1}\right)$ or different oxygen reduction kinetics (Scheme S4). It is unlikely that the former contributes to these differences as mutations are not close to the substrate-binding pocket. As for the latter, oxygen reduction kinetics are greatly oversimplified in the MM model, making it very difficult to obtain reliable information from a comparison among samples. However, it is valid to compare our results to published SLAC activities using different substrates (Table S2). Generally, our results fit in the range of published catalytic efficiencies, and thus it can be concluded that the mutant SLAC enzymes are catalytically active. We obtained higher catalytic rates using $\mathrm{ABTS}^{2-}$ as a substrate than in studies published by Sherif et al. ${ }^{16}$ The best catalytic performance was obtained using TMPD as a substrate with rates one order of magnitude higher than our results. This difference is likely due to the different redox chemistry of these two compounds. The midpoint potential of the $\mathrm{TMPD}^{\bullet}+\mathrm{TMPD}$ redox couple $\mathrm{E}_{1 / 2}\left(\mathrm{TMPD}^{\bullet}+\mathrm{TMPD}\right)=435 \mathrm{mV}^{17}$ vs. NHE, which is much lower than potential of the $\mathrm{ABTS}^{\bullet-} / \mathrm{ABTS}^{2-}$ redox couple $\left(\mathrm{E}_{1 / 2}\left(\mathrm{ABTS}^{\bullet-} / \mathrm{ABTS}^{2-}\right)=680 \mathrm{mV} \text { vs NHE}\right)^{18}$ and just 50 $\mathrm{mV}^{19}$ higher than potential of $\mathrm{Cu}_{\mathrm{T1}}{ }^{2+}$ in $2 \mathrm{D}$-laccases $\left(\mathrm{E}_{1 / 2}\left(\mathrm{Cu}_{\mathrm{T1}}{ }^{2+} / \mathrm{Cu}_{\mathrm{T1}}{ }^{+}\right)=375 \mathrm{mV}\right.$ vs NHE for the small laccase from Streptomyces sviceus). However, other factors such as different electrostatic properties and electrostatic interactions with SLAC's binding pocket could also affect catalytic turnover.

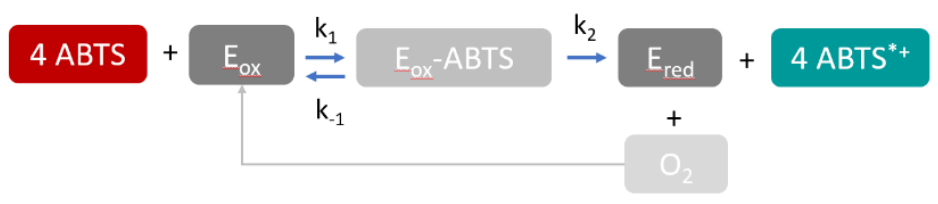

Scheme S4. Simplistic representation of the Michaelis-Menten model used for analyzing SLAC's enzymatic kinetics. $E_{O X}$ stands for an oxidized enzyme, $\mathrm{E}_{\mathrm{OX}}-\mathrm{ABTS}^{2-}$ represents the Enzyme-Substrate (ES) complex, and $\mathrm{E}_{\mathrm{RED}}$ is reduced enzyme. 


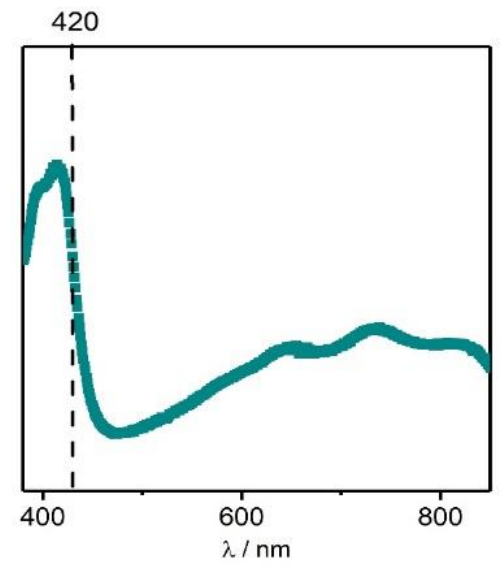

Figure S1. The UV-vis spectrum of $\mathrm{ABTS}^{--}$radical in $100 \mathrm{mM}$ acetate buffer $\mathrm{pH} 4.5$ obtained by one-electron oxidation of $\mathrm{ABTS}^{2-}$ by SLAC in the presence of oxygen. Changes in absorbance at $420 \mathrm{~nm}$ quantified the degree of $\mathrm{ABTS}^{2-}$ oxidation.

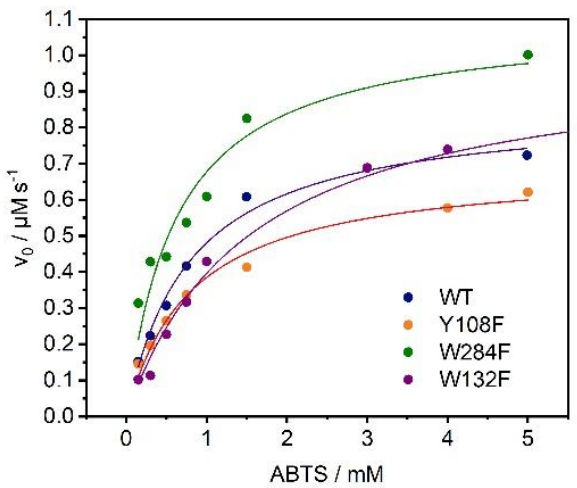

Figure S2. Rate of $\mathrm{ABTS}^{2-}$ oxidation by SLAC variants (WT - navy blue, Y108F - orange, W284F - green, W132F - purple) plotted against $\mathrm{ABTS}^{2-}$ concentration $(0.1-5 \mathrm{mM})$ measured in acetate buffer $\mathrm{pH} 4.5$ at $60{ }^{\circ} \mathrm{C}$ and $270 \mu \mathrm{M}$ $\mathrm{O}_{2}$. Dotted lines represent data, and solid lines represent the fitted Michaelis-Menten model.

Table S1. Michaelis-Menten constant $\left(\mathrm{K}_{\mathrm{M}}\right)$, rates of catalytic turnover $\left(\mathrm{k}_{\mathrm{CAT}}\right)$, and second-order rate constants $\left(\mathrm{k}_{\mathrm{CAT}} / \mathrm{K}_{\mathrm{M}}\right)$ of WT, Y108F, W132F, and W284F SLAC variants, derived from Michaelis-Menten experiments and analysis according to $K_{M}=\frac{k_{-1}+k_{2}}{k_{1}}, k_{C A T}=k_{2}$.

\begin{tabular}{|l|l|l|l|}
\hline & $\mathbf{K}_{\mathbf{M}} / \mathbf{m M}$ & $\mathbf{k}_{\mathrm{CAT}} / \mathbf{s}^{-1}$ & $\mathbf{k}_{\mathrm{CAT}} / \mathbf{K}_{\mathbf{M}} / \mathbf{M}^{-1} \mathbf{s}^{-1}$ \\
\hline $\mathbf{W T}$ & $0.98 \pm 0.3$ & $36 \pm 7$ & $36734 \pm 5840$ \\
\hline $\mathbf{Y 1 0 8 F}$ & $1.07 \pm 0.3$ & $32 \pm 5$ & $29906 \pm 3730$ \\
\hline $\mathbf{W 1 3 2 F}$ & $1.33 \pm 0.3$ & $38 \pm 4$ & $28571 \pm 2311$ \\
\hline $\mathbf{W 2 8 4 F}$ & $0.6 \pm 0.02$ & $35 \pm 3$ & $58333 \pm 2957$ \\
\hline
\end{tabular}


Table S2. Michaelis-Menten constants $\left(\mathrm{K}_{\mathrm{M}}\right)$, rates of catalytic turnover $\left(\mathrm{k}_{\mathrm{CAT}}\right)$ and second-order rate constants $\left(\mathrm{K}_{\mathrm{M}} / \mathrm{k}_{\mathrm{CAT}}\right)$ of SLAC samples with various substrates, as found in the literature. $\mathrm{pH}$, temp, and His-Tag conditions provide additional information about respective Michaelis-Menten experiments.

\begin{tabular}{|c|c|c|c|c|c|c|}
\hline Substrate & $\begin{array}{l}\mathrm{Km} / \\
\mathrm{mM}\end{array}$ & $\begin{array}{l}\text { kcat / } \\
\mathrm{s}^{-1}\end{array}$ & $\begin{array}{c}\text { kcat/K} / K_{M} \\
/ \mathbf{M}^{-1} \mathbf{s}^{-1}\end{array}$ & pH & $\begin{array}{l}\text { Temp / } \\
{ }^{\circ} \mathrm{C}\end{array}$ & His-Tag \\
\hline $\mathbf{D M P}^{20}$ & 2.7 & 10 & 3703 & 8.2 & RT & No \\
\hline DMP $^{16}$ & 1.1 & 4 & 3636 & 8 & 60 & No \\
\hline $\mathbf{A B T S}^{2-16}$ & 0.8 & 7.7 & 10000 & 4 & 60 & No \\
\hline $\left.\mathrm{Os}(\mathrm{dm}-\mathrm{bpy})_{2}(1-\mathrm{MeIm}) \mathrm{Cl}\right]_{2}{ }^{3}$ & 0.01 & 110 & 11000000 & 6 & RT & No \\
\hline $\mathbf{D M P}^{21}$ & 4 & 5.83 & 1400 & 7.2 & RT & Yes \\
\hline $\mathbf{D M P}^{22}$ & 2.85 & 0.87 & 305 & 8 & 30 & No \\
\hline DMP $^{19}$ & 0.89 & 0.32 & 350 & - & - & Yes \\
\hline $\mathbf{D M P}^{23}$ & 0.04 & 6 & 140000 & 8.5 & - & - \\
\hline TMPD $^{24}$ & 0.98 & 315 & 320000 & 6 & $\mathrm{RT}$ & No \\
\hline
\end{tabular}

\section{Single oxygen turnover experiments involving SLAC variants}

Solutions of SLAC variants in $10 \mathrm{mM}$ phosphate buffer $\mathrm{pH} 7.5$ were deoxygenated using evacuation/backfill cycles on a Schlenk line using Ar as inert gas. In a separate flask, a $10 \mathrm{mM}$ solution of ascorbic acid was deoxygenated in the same way. The experiment was initiated by the addition of $100 \mu \mathrm{L}$ of deoxygenated ascorbic acid solution as reductant to an air-tight cuvette containing $c a .2 \mathrm{~mL}$ of SLAC sample. Subsequently, UV-vis spectra were recorded until SLAC was completely reduced, indicated by loss of $\mathrm{Cu}_{\mathrm{T1}}{ }^{2+}$ (580 nm peak) absorbance. Single-oxygen turnover was initiated by the addition of ca. 250 $\mu \mathrm{L}$ of oxygenated $(270 \mu \mathrm{M})$ phosphate buffer. The initial concentrations of reagents are summarized in Table S3. The UV-vis spectra were recorded every $2 \mathrm{~s}$ up to 40 min until the sample was completely rereduced. Recorded spectra were baseline-corrected by fitting the background blank spectrum to a 5thdegree polynomial and subtracting it from the measured spectrum to remove the background signal. Component analysis was used to detect and assign 408, 424, and $583 \mathrm{~nm}$ absorptions by fitting Gaussian curves to the peaks. The time traces of $\mathrm{Cu}_{\mathrm{T} 1}{ }^{2+}$ and $\mathrm{Tyr}{ }^{\bullet}$ concentrations derived from spectral intensities are shown in Fig. S4. The time constants from fitted mono- and bi-exponential functions are summarized in Table S4. 
Table S3. The initial concentrations of reagents used in single-oxygen turnover experiments.

\begin{tabular}{|l|l|l|l|}
\hline & {$[$ Protein $] / \mu \mathbf{M}$} & {$\left[\mathbf{O}_{2}\right] / \mu \mathbf{M}$} & {$[$ Asc $] / \mu \mathbf{M}$} \\
\hline $\mathbf{W T}$ & 145 & 40 & 1153 \\
\hline $\mathbf{W 2 8 4 F}$ & 76.5 & 31 & 680 \\
\hline $\mathbf{W 1 3 2 F}$ & 190 & 70 & 710 \\
\hline Y108F & 57 & 52 & 900 \\
\hline
\end{tabular}
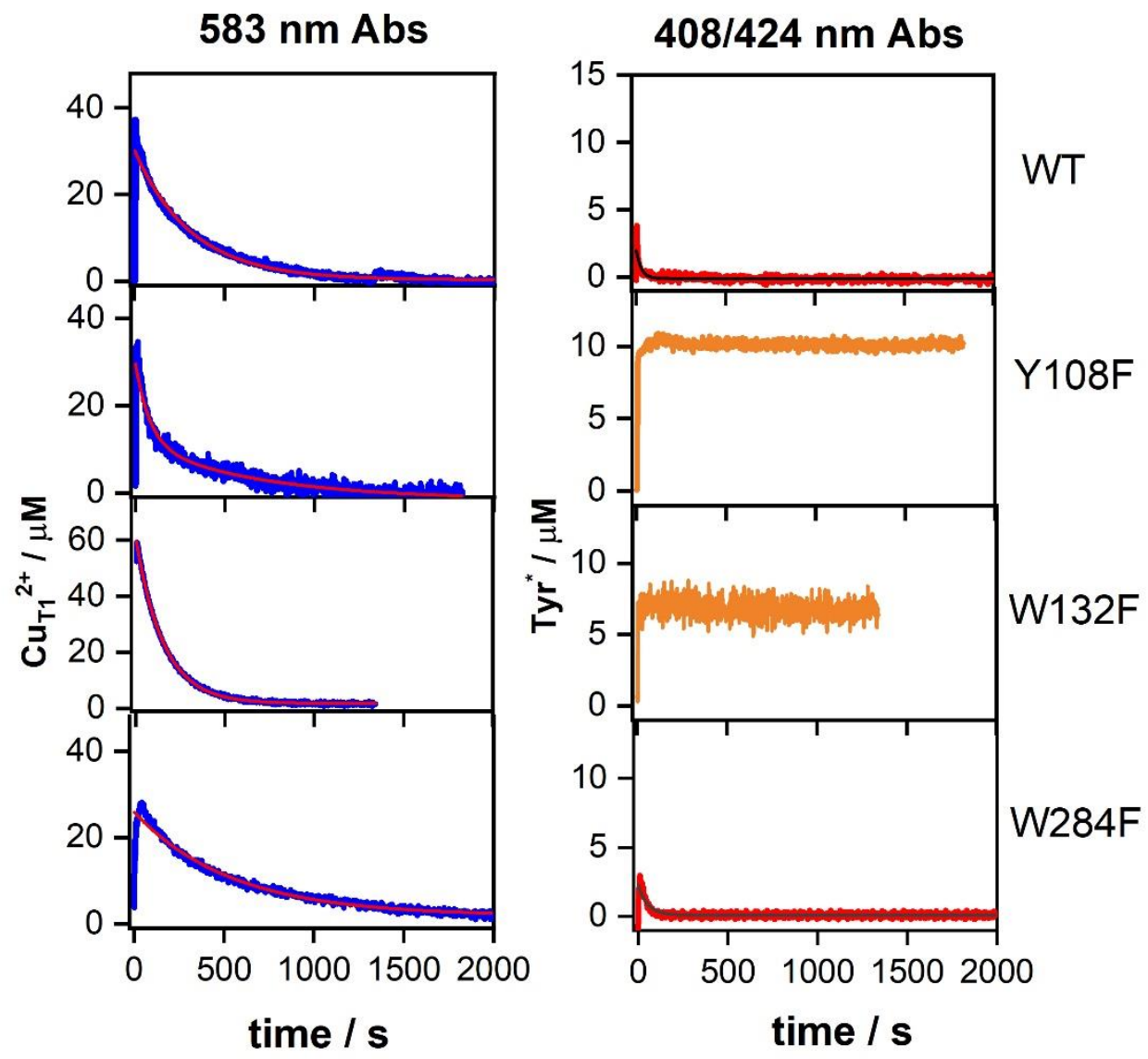

Figure S3. Time traces of concentrations of $\mathrm{Cu}_{\mathrm{T} 1}{ }^{2+}$ (left) and Tyr (right) in SLAC variants, calculated from spectral intensities of $583 \mathrm{~nm}$ and either $408 \mathrm{~nm}$ or $424 \mathrm{~nm}$ peaks, are shown as blue and red lines, respectively, fitted to mono or bi-exponential decay functions.

Table S4. Time constants $\left(\tau_{\exp }=1 / \mathrm{k}_{\mathrm{exp}}\right)$ extracted from fits to kinetics shown in Figure S4.

\begin{tabular}{|l|l|l|}
\hline & $\tau_{\exp }(\mathbf{5 8 3} \mathbf{n m}) / \mathrm{s}$ & $\tau_{\exp }(\mathbf{4 2 4} \mathbf{n m}) / \mathrm{s}$ \\
\hline WT & 316 & 27 \\
\hline W284F & 538 & 52 \\
\hline W132F & 154 & - \\
\hline Y108F & $670+80$ & - \\
\hline
\end{tabular}




\section{EPR measurements}

$\mathrm{A} \mathrm{Cu}_{\mathrm{T1}}$-depleted (T1D) W132F SLAC sample for EPR measurements was prepared in the same way as samples for single-oxygen turnover kinetics experiments. A deoxygenated protein solution $(180 \mu \mathrm{M})$ was mixed with a deoxygenated ascorbic acid solution until SLAC was completely reduced. Subsequently, the SLAC-ascorbic acid solution was mixed with oxygenated $10 \mathrm{mM}$ phosphate $\mathrm{pH} 7.5$ buffer containing glycerol, transferred to an EPR tube, and rapidly frozen in liquid nitrogen. The time between the addition of oxygenated solution to fully frozen sample was approximately $2 \mathrm{~min}$.

X-band CW EPR spectra of the T1D W132F sample were acquired on a Bruker (Billerica, MA) EMX spectrometer using Bruker Win-EPR software (ver. 3.0). Temperature control was achieved using liquid helium and an Oxford Instruments (Oxford, UK) ESR-900 cryogen flow cryostat with an ITC-503 temperature controller. The EPR spectrum was recorded at $40 \mathrm{~K}(9.64 \mathrm{GHz}$ microwave frequency with $2.036 \mathrm{~mW}$ microwave power, $8 \mathrm{G}$ modulation amplitude, and $20.48 \mathrm{~ms}$ conversion time). 40 scans were recorded and averaged (Fig. S3).

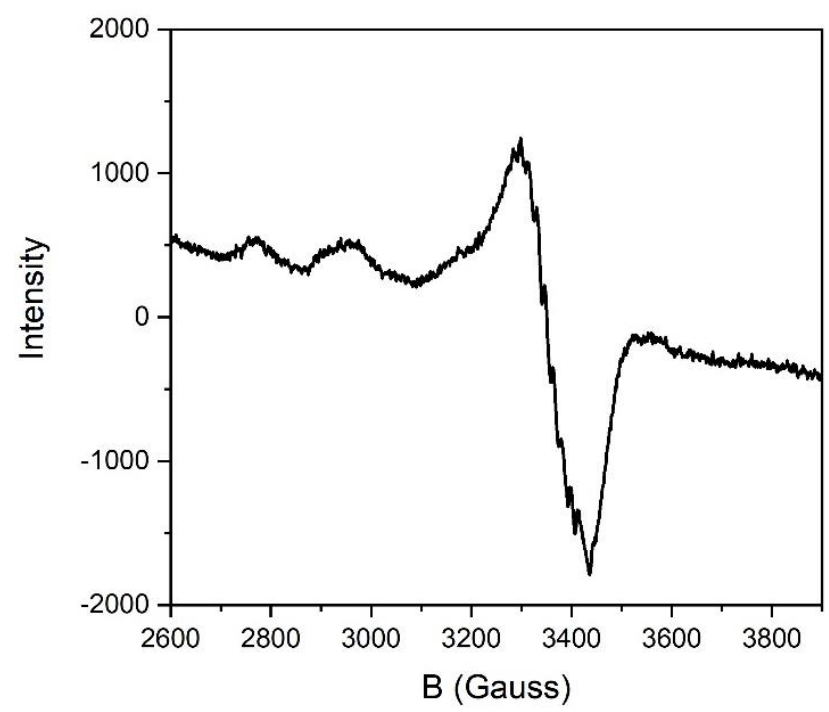

Figure S4. The X-band EPR spectrum of T1D W132F SLAC variant, recorded at $40 \mathrm{~K}(9.64 \mathrm{GHz}$ microwave frequency, $2.036 \mathrm{~mW}$ microwave power, and $8 \mathrm{G}$ modulation amplitude). 


\section{References}

(1) Skálová, T.; Dohnálek, J.; Østergaard, L. H.; Østergaard, P. R.; Kolenko, P.; Dušková, J.; Štěpánková, A.; Hašek, J. The Structure of the Small Laccase from Streptomyces Coelicolor Reveals a Link between Laccases and Nitrite Reductases. J. Mol. Biol. 2009, 385 (4), 1165-1178. https://doi.org/10.1016/j.jmb.2008.11.024.

(2) Durão, P.; Chen, Z.; Fernandes, A. T.; Hildebrandt, P.; Murgida, D. H.; Todorovic, S.; Pereira, M. M.; Melo, E. P.; Martins, L. O. Copper Incorporation into Recombinant CotA Laccase from Bacillus Subtilis: Characterization of Fully Copper Loaded Enzymes. J. Biol. Inorg. Chem. 2008, 13 (2), 183-193. https://doi.org/10.1007/s00775-007-0312-0.

(3) Gallaway, J.; Wheeldon, I.; Rincon, R.; Atanassov, P.; Banta, S.; Barton, S. C. Oxygen-Reducing Enzyme Cathodes Produced from SLAC, a Small Laccase from Streptomyces Coelicolor. Biosens. Bioelectron. 2008, 23 (8), 1229-1235. https://doi.org/10.1016/j.bios.2007.11.004.

(4) Gill, S. C.; von Hippel, P. H. Calculation of Protein Extinction Coefficients from Amino Acid Sequence Data. Anal. Biochem. 1989, 182 (2), 319-326. https://doi.org/10.1016/00032697(89)90602-7.

(5) Brenner, A. J.; Harris, E. D. A Quantitative Test for Copper Using Bicinchoninic Acid. Analytical Biochemistry. 1995, pp 80-84. https://doi.org/10.1006/abio.1995.1194.

(6) Huang, T.; Long, M.; Huo, B. Competitive Binding to Cuprous Ions of Protein and BCA in the Bicinchoninic Acid Protein Assay. Open Biomed. Eng. J. 2010, 4, 271-278. https://doi.org/10.2174/1874120701004010271.

(7) Thermo Scientific. User Guide: Pierce BCA Protein Assay Kit. Pierce Biotechnol. 2011, 0747 (23225), 1-7. https://doi.org/10.1016/j.ijproman.2010.02.012.

(8) Gabdulkhakov, A. G.; Kostareva, O. S.; Kolyadenko, I. A.; Mikhaylina, A. O.; Trubitsina, L. I.; Tishchenko, S. V. Incorporation of Copper Ions into T2/T3 Centers of Two-Domain Laccases. Mol. Biol. 2018, 52 (1), 23-29. https://doi.org/10.1134/S0026893318010041.

(9) Solomon, E. I.; Heppner, D. E.; Johnston, E. M.; Ginsbach, J. W.; Cirera, J.; Qayyum, M.; KieberEmmons, M. T.; Kjaergaard, C. H.; Hadt, R. G.; Tian, L. Copper Active Sites in Biology. Chem. Rev. 2014, 114 (7), 3659-3853. https://doi.org/10.1021/cr400327t.

(10) Tazhigulov, R. N.; Gayvert, J. R.; Wei, M.; Bravaya, K. B. EMap: A Web Application for Identifying and Visualizing Electron or Hole Hopping Pathways in Proteins. J. Phys. Chem. B 2019, 123 (32), 6946-6951. https://doi.org/10.1021/acs.jpcb.9b04816.

(11) Marcus, R. A.; Sutin, N. Electron Transfers in Chemistry and Biology. Biochim. Biophys. Acta Rev. Bioenerg. 1985, 811 (3), 265-322. https://doi.org/10.1016/0304-4173(85)90014-X.

(12) Beratan, D. N.; Onuchic, J. N.; Winkler, J. R.; Gray, H. B. Electron-Tunneling Pathways in Proteins. Science (80-. ). 1992, 258 (5089).

(13) Onuchic, J. N.; Beratan, D. N.; Winkler, J. R.; Gray, H. B. Pathway Analysis of Protein ElectronTransfer Reactions. Annu. Rev. Biophys. Biomol. Struct. 1992, 21.

(14) Pardo, I.; Camarero, S. Laccase Engineering by Rational and Evolutionary Design. Cell. Mol. Life 
Sci. 2015, 72 (5), 897-910. https://doi.org/10.1007/s00018-014-1824-8.

(15) Christenson, A.; Dimcheva, N.; Ferapontova, E. E.; Gorton, L.; Ruzgas, T.; Stoica, L.; Shleev, S.; Yaropolov, A. I.; Haltrich, D.; Thorneley, R. N. F.; Aust, S. D. Direct Electron Transfer Between Ligninolytic Redox Enzymes and Electrodes. Electroanalysis 2004, 16 (1314), 1074-1092. https://doi.org/10.1002/elan.200403004.

(16) Sherif, M.; Waung, D.; Korbeci, B.; Mavisakalyan, V.; Flick, R.; Brown, G.; Abou-Zaid, M.; Yakunin, A. F.; Master, E. R. Biochemical Studies of the Multicopper Oxidase (Small Laccase) from Streptomyces Coelicolor Using Bioactive Phytochemicals and Site-Directed Mutagenesis. Microb. Biotechnol. 2013, 6 (5), 588-597. https://doi.org/10.1111/1751-7915.12068.

(17) Long, J. S.; Silvester, D. S.; Barnes, A. S.; Rees, N. V.; Aldous, L.; Hardacre, C.; Compton, R. G. Oxidation of Several P-Phenylenediamines in Room Temperature Ionic Liquids: Estimation of Transport and Electrode Kinetic Parameters. J. Phys. Chem. C 2008, 112 (17), 6993-7000. https://doi.org/10.1021/jp800235t.

(18) Scott, S. L.; Chen, W. J.; Bakac, A.; Espenson, J. H. Spectroscopic Parameters, Electrode Potentials, Acid Ionization Constants, and Electron Exchange Rates of the 2,2'-Azinobis(3Ethylbenzothiazoline-6-Sulfonate) Radicals and Ions. J. Phys. Chem. 1993, 97 (25), 6710-6714. https://doi.org/10.1021/j100127a022.

(19) Gunne, M.; Höppner, A.; Hagedoorn, P. L.; Urlacher, V. B. Structural and Redox Properties of the Small Laccase Ssl1 from Streptomyces Sviceus. FEBS J. 2014, 281 (18), 4307-4318. https://doi.org/10.1111/febs.12755.

(20) Machczynski, M. C.; Vijgenboom, E.; Samyn, B.; Canters, G. W. Characterization of SLAC: A Small Laccase from Streptomyces Coelicolor with Unprecedented Activity. Protein Sci. 2004, 13 (9), 2388-2397. https://doi.org/Doi 10.1110/Ps.04759104.

(21) Wheeldon, I. R.; Gallaway, J. W.; Barton, S. C.; Banta, S. Bioelectrocatalytic Hydrogels from Electron-Conducting Metallopolypeptides Coassembled with Bifunctional Enzymatic Building Blocks. Proc. Natl. Acad. Sci. U. S. A. 2008, 105 (40), 15275-15280. https://doi.org/10.1073/pnas.0805249105.

(22) Toscano, M. D.; De Maria, L.; Lobedanz, S.; Østergaard, L. H. Optimization of a Small Laccase by Active-Site Redesign. ChemBioChem 2013, 14 (10), 1209-1211. https://doi.org/10.1002/cbic.201300256.

(23) Cook, R.; Hannon, D.; Southard, J. N.; Majumdar, S. Small Laccase from Streptomyces Coelicolor -an Ideal Model Protein/Enzyme for Undergraduate Laboratory Experience. Biochem. Mol. Biol. Educ. 2017, 1-10. https://doi.org/10.1002/bmb.21102.

(24) Gupta, A.; Nederlof, I.; Sottini, S.; Tepper, A. W. J. W.; Groenen, E. J. J.; Thomassen, E. A. J.; Canters, G. W. Involvement of Tyr108 in the Enzyme Mechanism of the Small Laccase from Streptomyces Coelicolor. J. Am. Chem. Soc. 2012, 134 (44), 18213-18216. https://doi.org/10.1021/ja3088604. 
